\title{
Subcostal Artery
}

National Cancer Institute

\section{Source}

National Cancer Institute. Subcostal Artery. NCI Thesaurus. Code C53000.

An artery arising from the thoracic aorta that runs along the bottom of the twelfth rib. 